\title{
ANALISIS KINERJA KEUANGAN PADA KOPERASI PEGAWAI REPUBLIK INDONESIA (KPRI) DI KOTA PEKANBARU
}

\section{ANALYSIS OF EMPLOYEE COOPERATIVE FINANCIAL PERFORMANCE THE REPUBLIC OF INDONESIA IN PEKANBARU CITY}

\author{
Machasin ${ }^{1}$, Ezky Tiyasiningsih², Arika Fitriani ${ }^{3}$ \\ 1 Universitas Riau; Pekanbaru \\ ${ }^{2}$ Universitas Riau; Pekanbaru \\ ${ }^{3}$ Universitas Riau; Pekanbaru \\ Machasin62@yahoo.co.id
}

\begin{abstract}
ABSTRAK
Koperasi Pegawai Republik Indonesia (KPRI) di Kota Pekanbaru masih mengalami proporsi modal yang tidak seimbang. Kondisi ini yang menjadikan koperasi sebagai kreditor memiliki risiko tinggi, karena koperasi masih belum cukup memiliki modal sendiri untuk digunakan dalam kegiatan bisnis di kota Pekanbaru. Tujuan penelitian ini untuk meneliti kinerja keuangan KPRI di Kota Pekanbaru berdasarkan Rasio Likuiditas ditinjau dari Curent Ratio, kinerja keuangan KPRI di Kota Pekanbaru berdasarkan Rasio Solvabilitas dalam hal Jumlah Hutang (Kewajiban) Terhadap Aset dan Total Hutang (Kewajiban) Terhadap Modal Sendiri, kinerja keuangan KPRI di Kota Pekanbaru berdasarkan Rasio Profitabilitas / Rentabilitas yang berasal dari Net Profit Margin, Return On Asset (ROA), dan Rentability of Own Capital dan kinerja keuangan KPRI di Kota Pekanbaru berdasarkan Rasio Aktivitas dalam hal Perputaran Piutang dan Perputaran Aset di kota Pekanbaru

Kata Kunci: Kinerja Keuangan
\end{abstract}

\begin{abstract}
The Republic of Indonesia Employee Cooperative (KPRI) in Pekanbaru City still experiences an unbalanced proportion of capital. This condition makes cooperatives as creditors have a high risk, because cooperatives still do not have enough capital to use in business activities in the city of Pekanbaru. The purpose of this research is to examine the financial performance of KPRI in Pekanbaru City based on the Liquidity Ratio in terms of Curent Ratio, KPRI financial performance in Pekanbaru City based on Solvability Ratios in terms of Total Debt (Assets) on Assets and Total Debt (Obligations) on Own Capital, KPRI financial performance in Pekanbaru City based on Profitability / Rentability Ratios derived from Net Profit Margin, Return On Assets (ROA), and Rentability of Own Capital and KPRI financial performance in Pekanbaru City based on Activity Ratios in Accounts Receivable Turnover and Asset Turnover in Pekanbaru City Keywords: Financial Performance
\end{abstract}




\section{PENDAHULUAN}

Koperasi merupakan salah satu organisasi ekonomi yang memiliki ruang gerak dan kesempatan usaha yang menyangkut kepentingan kehidupan ekonomi rakyat. Selain itu, gerakan koperasi juga didasarkan pada parameter efisiensi yang berkaitan dengan promosi keunggulan dan peningkatan efisiensi operasional yang mengarah pada pembangunan dan pengembangan potensi serta kemampuan ekonomi anggota pada khususya dan masyarakat pada umumnya untuk meningkatkan kesejahteraan ekonomi dan sosialnya.

Merunut pada pasal 33 ayat 1 UUD 1945 bahwa peran koperasi sangatlah penting dalam menumbuhkan dan mengembangkan potensi ekonomi rakyat serta dalam mewujudkan kehidupan demokrasi ekonomi yang mempunyai ciri-ciri demokrasi, kebersamaan, kekeluargaan dan keterbukaan. Sebagaimana halnya dengan Badan Usaha lain (Badan Usaha Milik Negara dan Badan Usaha Milik Swasta). Koperasi juga perlu dikelola dengan baik agar dapat berkembang menjadi badan usaha yang sehat sehingga dapat memberikan manfaat bagi anggota dan masyarakat.

Sementara itu cara yang digunakan untuk mengetahui pengelolaan dan kualitas kemampuan suatu koperasi adalah dengan menggunakan kriteria serta standar penilaian yang ditetapkan oleh Peraturan Menteri Negara Koperasi dan Usaha Kecil dan Menengah No. 14/Per/M.KUKM/XII/2009. Peraturan menteri tersebut sebagai acuan dalam pelaksanaan klasifikasi koperasi secara nasional berdasarkan penjabaran prinsip-prinsip koperasi.

Koperasi Pegawai Republik Indonesia (KPRI) merupakan salah satu jenis koperasi primer dimana para anggotanya merupakan para pegawai negeri yang berpenghasilan tetap. Dengan adanya penghasilan tetap maka koperasi tersebut dapat memobilisasi dana dengan menggerakan simpanan anggotanya secara teratur. Lebih lanjut, KPRI juga merupakan koperasi golongan konsumen. Namun demikian, dalam perkembangannya sudah tentu koperasi konsumen bertujuan untuk memelihara kepentingan dan memenuhi kebutuhan para anggotanya (keluarga pegawai negeri sebagai konsumen) dengan menjalankan kegiatan usaha di bidang niaga maupun di bidang produksi dan sebagainya. Apalagi jika mengingat bahwa kesejahteraan pegawai negeri menyangkut serangkaian kebutuhan yang paling dirasakan dewasa ini, yaitu pangan, sandang, pemukiman, pendidikan dan kesehatan. Perjuangan dan aktivitas KPRI hendaknya diarahkan ke tujuan: (1) Minimal mempertahankan tingkat hidup anggota-anggotanya sebagai landasan dan pangkal tolak untuk meningkatkan kesejahteraan hidupnya; (2) Maksimal memperbaiki kesejahteraan anggotaanggotanya dengan jalan menjalankan aktivitas usaha koperasi sebaik-baiknya sehingga dapat menghasilkan sisa hasil usaha yang optimal.

Dalam rangka mengetahui dan menilai kinerja KPRI di Kota Pekanbaru, dalam proses mencapai tujuan, diperlukan adanya pengukuran terhadap kinerja. Menurut Darmawati (2007), "Koperasi dianggap sehat apabila mampu mengelola keuangan atau sumber daya yang ada. Pengelolaan keuangan yang baik akan mampu meningkatkan pendapatan anggotanya." Laporan keuangan dapat memberi informasi sehubungan dengan kondisi keuangan dan hasil yang telah dicapai oleh koperasi tersebut, dari periode tertentu. Untuk memperoleh informasi tersebut, laporan keuangan haruslah dianalisis. Melalui analisis keuangan diharapkan dapat diketahui kekuatan dan kelemahan perusahaan dengan menggunakan informasi yang terdapat dalam laporan keuangan. Di Kota Pekanbaru terdapat 104 Koperasi KPRI, dengan 75 Koperasi yang masih aktif dan 29 Koperasi yang tidak aktif.

Koperasi Pegawai Republik Indonesia (KPRI) di Kota Pekanbaru masih mengalami proporsi permodalan yang tidak seimbang. Kondisi tersebut yang membuat koperasi selaku pihak 
kreditur mempunyai resiko yang tinggi, karena koperasi masih belum cukup memiliki modal sendiri untuk digunakan dalam kegiatan usahanya. Oleh karena itu ketika koperasi menjalankan kegiatan usahanya dan membutuhkan dana segar maka dipergunakanlah fasilitas hutang. Kondisi yang demikian bisa sangat berpengaruh terhadap kinerja koperasi. Berdasarkan latar belakang maka diambil lah judul "Analisis Kinerja Keuangan pada Koperasi Pegawai Republik Indonesia (KPRI) di Kota Pekanbaru".

Berdasarkan uraian pada latar belakang diatas maka tujuan penelitian ini adalah 1) Untuk mengetahui kinerja keuangan KPRI di Kota Pekanbaru berdasarkan Rasio Likuiditas di tinjau dari Curent Ratio, 2) Untuk mengetahui kinerja keuangan KPRI di Kota Pekanbaru berdasarkan Rasio Solvabilitas dengan ditinjau dari Total Hutang (Kewajiban) Terhadap Aset dan Total Hutang (Kewajiban) Terhadap Modal Sendiri, 3) Untuk mengetahui kinerja keuangan KPRI di Kota Pekanbaru berdasarkan Rasio Profitabilitas/ Rentabilitas ditinaju dari Net Profit Margin, Retrun On Asset (ROA), dan Rentabilitas Modal Sendiri, 4) Untuk mengetahui kinerja keuangan KPRI di Kota Pekanbaru berdasarkan rasio aktivitas ditinjau dari perputaran piutang dan perputaran aktiva.

\section{LANDASAN TEORI}

\section{Pengertian Koperasi}

Di Indonesia penegrtian Koperasi menurut Undang-Undang koperasi No 12 Tahun 1967, tentang pokok-pokok perkoperasian yaitu: Koperasi Indonesia adalah organisasi ekonomi rakyat yang berwatak sosial beranggotakan orang-orang atau badan-badan hukum koperasi yang meruapakan tata susunan ekonomi sebagai usaha bersama berdasarkan atas asas kekeluargaan.

Selain pengertian koperasi menurut Undang-Undang koperasi No 12 Tahun 1967, dalam Undang-Undang 1945 pasal 33 ayat 1 juga telah digariskan bahwa: perekonomian Indonesia disusun secara usaha bersama dan berdasarkan atas asas kekeluargaan. Kemudian ditegaskan dalam penjelasan Undang-Undang 1945 pasal 33 ayat 1 bahwa: Bangun perusahaan yang sesuai dengan itu ialah kopersi. Sedangkan dalam ketetapan MPR dinyatakan bahwa: Koperasi harus digunakan sebagi salah satu wadah utama untuk membina kemampuan usaha golongan ekonomi lemah.

Menurut Rudianto (2010:4) tujuan koperasi di Indonesia menurut garis besarnya meliputi tiga hal, antara lain; 1) Untuk memajukan kesejahteraan anggotanya, 3) Untuk memajukan kesejahteraan masyarakat, dan 3) Turut serta membangun tatanan perekonomian nasional.

Berdasarkan ketiga tujuan tersebut dapat disimpulkan koperasi memiliki tujuan untuk memajukan kesejahteraan anggota dan masyarakat dan koperasi memiliki tujuan secara spesifik yaitu turut serta membangun tatanan perekonomian nasional. Karena asas kekeluargaan dapat mendorong bersatunya pemerintah dan masyarakat untuk mengembangkan dan meningkatkan perekonomian nasional.

Koperasi sangat membantu perkembangan ekonomi anggotanya, karena dengan bergabung dengan koperasi, koperasi dapat mensejahterakan anggota. Modal serta kinerja anggota koperasi mendukung koperasi dalam mengembangkan koperasi. Koperasi juga membantu perekonomian masyarakat sekitar, koperasi simpan pinjam, masyarakat terbantu saat akan meminjam dana ke koperasi. 


\section{Prinsip-prinsip Koperasi}

Perbedaan antara koperasi dengan bentuk usaha lainnya tidak hanya pada landasan dan asas koperasi, tetapi juga pada prinsip-prinsip pengelolaan koperasi dan usaha yang dianutnya. Prinsip-prinsip koperasi biasanya mengatur hubungan anggota koperasi dengan koperasi, hubungan antara sesama anggota koperasi dan prinsip koperasi yang berlandaskan kekeluargaan.

Penyusunan prinsip-prinsip koperasi di Indonesia tidak terlepas dari sejarah dan perkembangan prinsip koperasi internasional. Sebagaimana dinyatakan dalam pasal 5 ayat $1 \mathrm{UU}$ No.25/1992 dalam (Rudianto, 2010:4) prinsip-prinsip koperasi antara lain : 1) Keanggotaan bersifat sukarela dan terbuka, 2) Pengelolaan dilakukan secara demokratis, 3) Pembagian sisa hasil usaha yang dilakukan secara adil dan sebanding dengan besarnya jasa masing-masing anggota, 4) Pemberian balas jasa yang terbatas pada modal, 5) Kemandirian.

Berdasarkan prinsip-prinsip koperasi di atas, koperasi yang akan menjadi anggota koperasi tidak boleh dipaksa oleh orang lain untuk menjadi anggota koperasi sehingga anggota koperasi secara sukarela untuk menjadi anggota koperasi. Dalam pengambilan keputusan di koperasi, anggota harus diikutsertakan dalam pengambilan keputusan karena anggota koperasi juga penting dalam koperasi, pengambilan keputusan harus diputuskan secara demokratis karena untuk mengembangkan koperasi. Koperasi tidak menggunakan istilah laba atau keuntungan untuk menunjukkan selisih antara penghasilan yang diterima selama periode tertentu serta jasa anggota. Selisih itu disebut dengan sisa hasil usaha (SHU), koperasi dalam pembagian sisa hasil usaha (SHU) harus didasarkan pada kontribusi dan jasa para anggota koperasi.

Koperasi dalam pemberian balas jasa terbatas pada modal, modal pada koperasi yang rendah memungkinkan pemberian balas jasa juga rendah, sehingga koperasi mendorong rasa kesetiakawanan untuk mengerti kondisi koperasi serta koperasi mendorong semangat untuk memajukan dan mengembangkan koperasi. Koperasi untuk mencapai kemandirian harus memperjuangkan kepentingan untuk meningkatkan koperasi di kalangan masyarakat serta kesejahteraan perekonomian, karena koperasi merupakan badan usaha yang membantu perkembangan perekonomian nasional.

Dilihat dari bidang usaha dan jenis anggotanya, koperasi dikelompokkan menjadi 4 jenis. Menurut PSAK No.27 Tahun 2007 dalam (Rudianto,2010:5-6) koperasi dapat dikelompokkan ke dalam beberapa jenis, antara lain: 1) Koperasi Simpan Pinjam adalah koperasi yang bergerak dalam bidang pemupukan simpanan dana dari para anggotanya, 2) Koperasi konsumen adalah koperasi yang anggotanya terdiri dari para konsumen akhir atau pemakai barang atau jasa, 3) Koperasi pemasaran adalah koperasi yang anggotanya terdiri dari para konsumen atau pemilik barang atau penyedia jasa. 4) Koperasi produsen adalah koperasi yang para anggotanya tidak memilki badan usaha sendiri tetapi bekerja sama dalam wadah koperasi untuk menghasilkan dan memasarkan barang atau jasa.

\section{Modal Koperasi}

Menurut Rudianto (2010:6-7) modal koperasi terdiri dari : 1) Modal anggota sebagai sumber pembelanjaan usaha yang berasal dari setoran para anggota. Setoran anggota koperasi dikelompokkan menjadi 3 antara lain : a) Simpanan pokok adalah jumlah nilai uang tertentu yang sama banyaknya yang harus disetorkan oleh setiap anggota pada waktu masuk menjadi anggota koperasi. Jenis simpanan ini tidak dapat diambil kembali selama orang tersebut masih menjadi 
anggota koperasi, b) Simpanan wajib adalah jumlah nilai uang tertentu yang harus dibayarkan oleh anggota dalam waktu dan kesempatan tertentu seperti sebulan sekali. Jenis simpanan ini dapat diambil kembali dengan cara yang diatur lebih lanjut dalam anggaran dasar, anggaran rumah tangga dan keputusan rapat anggota.Simpanan sukarela adalah jumlah tertentu yang diserahkan oleh anggota atau bukan anggota kepada koperasi atas kehendak sendiri sebagai simpanan. Simpanan sukarela tidak dapat dikelompokkan sebagai modal anggota koperasi dalam koperasi tetapi dikelompokkan sebagai utang jangka pendek. 2) Modal sumbangan adalah sejumlah uang atau barang modal yang dapat dinilai dengan yang diterima dari pihak lain yang bersifat hibah dan tidak mengikat., 3) Modal penyertaan adalah sejumlah uang atau barang modal yang dapat dinilai dengan uang yang ditanamkan oleh pemodal untuk menambah dan memperkuat struktur permodalan dalam meningkatkan usaha koperasi, 4) Cadangan adalah bagian dari sisa hasil usaha (SHU) yang disisihkan oleh koperasi untuk suatu tujuan tertentu sesuai dengan ketentuan anggaran dasar atau ketetapan rapat anggota, 5) Sisa hasil usaha (SHU) adalah selisih antara penghasilan yang diterima koperasi selama periode tertentu dengan pengorbanan yang dikeluarkan untuk memperoleh penghasilan itu.

\section{Laporan Keuangan Koperasi}

Laporan keuangan koperasi adalah laporan pertanggungjawaban pengurus atau manajemen tentang koperasi. Selain itu, laporan keuangan koperasi juga merupakan bagian dari sistem pelaporan keuangan koperasi. Pemakai utama dari laporan keuangan koperasi adalah para anggota koperasi beserta pengurus atau manajemen koperasi. Pemakai lainnya adalah calon anggota koperasi, bank, kreditor dan kantor pajak.

Baridwan dalam Rachmawati (2013), laporan keuangan adalahlaporan ringkas dari suatu proses pencatatan dari transaksi-transaksi keuangan yang terjadi selama tahun buku yang bersangkutan. Laporan keuangan dibuat oleh manajemen dengan tujuan untuk mempertanggungjawabkan tugas-tugas yang dibebankan kepada manajemen oleh para pemilik perusahaan laporan keuangan dapat tujuan-tujuan kepada pihak di luar perusahaan.

Penyajian laporan keuangan oleh suatu koperasi dimaksudkan untuk memberikan informasi mengenai keadaan keuangan koperasi pada suatu periode tertentu baik untuk manajemen, pemilik koperasi, pemerintah maupun pihak lain. Ikatan Akuntan Indonesia dalam Standar Akuntansi Keuangan (2007:3) menyatakan bahwa tujuan laporan keuangan adalah 1) Menyediakan informasi yang menyangkut posisi keuangan, kinerja serta perubahan posisi keuangan suatu koperasi yang bermanfaat bagi sejumlah besar pemakaian dalam pengambilan keputusan ekonomi, 2) Memenuhi kebutuhan bersama sebagian besar pemakai untuk mengambil keputusan ekonomi dan menggambarkan pengaruh keuangan dari kejadian masa lalu dan tidak diwajibkan untuk menyediakan informasi non keuangan, 3) Menunjukkan pertanggungjawaban manajemen atas sumber daya yang dipercayakan kepadanya.

\section{METODE PENELITIAN}

\section{Lokasi dan Waktu Penelitian}

Lokasi penelitian adalah Kota Pekanbaru, dengan jumlah Koperasi Pegawai Republik Indonesia yang di jadikan sampel yaitu sebanyak 10 Koperasi. Waktu penelitian dilakukan selama 6 bulan yaitu pada bulan April 2018 sampai September 2018. 


\section{Jenis dan Sumber Data}

Menurut Umar (2008) jenis data yang digunakan dalam penelitian ini ada dua jenis data, yaitu : 1) Data primer, yaitu data yang diperoleh langsung dari sumber pertama baik dari individu atau perseorangan seperti hasil pengisian kuisioner yang dilakukan oleh peneliti dan mewawancarai pihak-pihak terkait, serta data lain yang ada hubungannya dengan penelitian. Dalam penelitian ini yang menjadi sumber data primer adalah kelompok sasaran dan petugas yang berkecimpung dalam penanganan langsung dari Dinas Koperasi, Koperasi, 2) Data Sekunder, yaitu data yang telah diolah dan telah tersaji serta telah ter dokumentasi. Dimana datanya yang dilihat dari aspek dana pihak ke 3 , data pelatihan, data prasurvey dan data lain yang relevan dengan penelitian ini, sedangkan keknik pengumpulan data yang digunakan pada penelitian ini adalah Observasi, Wawancara (Interview) dan Dokumentasi

\section{Metode Analisis Data}

Metode yaang digunakan dalam menganalisis data pada penelitian ini berupa metode deskriptif dengan menggunakan pendekatan kuantitatif dan penghitungan analisis rasio keuangan berdasarkan Peraturan Menteri Negara Koperasi dan UKM Republik Indonesia Nomor 06/Per/M.KUKM/V/2006, tentang pedoman penilaian koperasi berprestasi yang mengacu pada aspek produktivitas.

\section{Analisis Rasio}

1) Rasio Likuiditas; Menurut Munawir (2001), Rasio likuiditas adalah rasio yang mengukur kemampuan perusahaan dalam membayar kewajiban jangka pendek pada saat jatuh tempo serta menunjukkan jumlah waktu yang diharapkan sampai suatu aktiva teralisasi menjadi kas atau sampai kewajiban koperasi perusahaan dilunasi, dengan rumus sebagai berikut :

$$
\text { Rasio Lancar(CurenRatio) }=\frac{\text { Aktiva Lancar }}{\text { Pasiva Lancar }} \times 100 \%
$$

2) Rasio Solvabilitas; Menurut Munawir (2001), Rasio Solvabilitas menunjukkan kemampuan perusahaan untuk memenuhi segala kewajiban keuangan apabila perusahaan tersebut dilikuidasikan, baik keuangan jangka pendek maupun jangka panjang, dengan rumus sebagai berikut :

Total Hutang (Kewajiban) TerhadapAset $=\frac{\text { Total Hutang }}{\text { Total Aset }} \times 100 \%$

$$
\text { Total Hutang (Kewajiban)TerhadapModal Sendiri }=\frac{\text { Total Hutang }}{\text { ModalSendiri }} \times 100 \%
$$

3) Rasio Profitabilitas/ Rentabilitas; Munawir (2001) Rentabilitas suatu perusahaan diukur dengan kesuksesan perusahaan dan kemampuan menggunakan aktivanya secara produktif dengan demikian rentabilitas suatu perusahaan dapat diketahui dengan memperbandingkan antara laba yang diperoleh dalam suatu periode dengan jumlah aktiva atau jumlah modalnya. Rasio Rentabilitas yang dapat digunakan adalah :

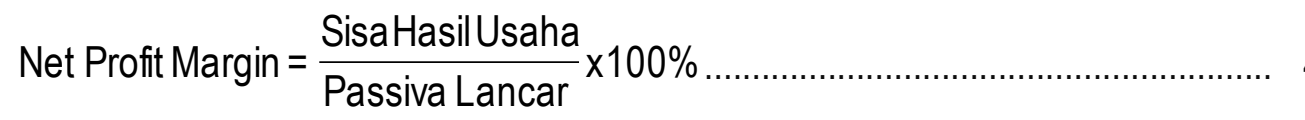

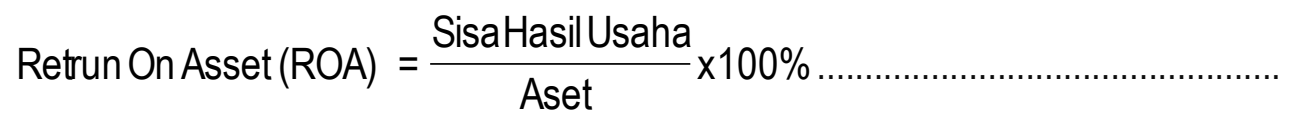




$$
\text { Rentabilitas ModalSendiri }=\frac{\text { SisaHasil Usaha }}{\text { ModalSendiri }} \times 100 \%
$$

4) Rasio Aktivitas

$$
\begin{aligned}
& \text { Perputaran Piutang }=\frac{\text { Pendapatan }}{\text { Saldo Piutang }(\text { Thn Sebelumnya }+ \text { Thn Saatini })} \times 1 \text { Kali .......... 7) } \\
& \text { Perputaran Aktiva }=\frac{\text { VolumeUsaha }}{\text { Aset }} \times 1 \text { Kali ...................................................... 8) }
\end{aligned}
$$

\section{HASIL DAN PEMBAHASAN}

\section{Rasio Likuiditas}

Rasio ini digunakan untuk mengetahui kemampuan KPRI di Kota Pekanbaru, dalam memenuhi segala kewajiban keuangan. Rasio likuiditas yang cukup besar menunjukkan kemampuan koperasi tersebut dalam memenuhi kewajibannya yang jatuh tempo dengan cukup baik.

\section{Analisis Rasio Lancar (Curent Ratio)}

Curent ratio adalah perbandingan antara jumlah aktivalancar dengan hutang lancer. Perhitungan current ratio dari laporan keuangan KPRI di Kota Pekanbaru pada Tahun 2015, 2016 dan 2017 dan hasil perhitungan current ratio dapat dilihat pada Tabel sebagai berikut :

Tabel 3. Perhitungan Curent Ratio

\begin{tabular}{|l|c|c|c|c|c|}
\hline Tahun & Aktiva Lancar (Rp) & $\begin{array}{c}\text { Pasiva Lancar } \\
(\text { Rp) }\end{array}$ & Curent Ratio & Nilai & Kriteria \\
\hline 1. KOPERASI SITI PAYUNG & \multicolumn{5}{|l|}{} \\
\hline 2015 & 678.119 .557 & 188.042 .860 & $360,62 \%$ & 0 & Tidak Baik \\
\hline 2016 & 826.331 .819 & 333.909 .346 & $247,47 \%$ & 100 & Sangat Baik \\
\hline 2017 & 529.907 .294 & 421.76 .373 & $1.256,41 \%$ & 0 & Tidak Baik \\
\hline 2. KOPERASI MAN 2 \& MTsN PEKANBARU \\
\hline 2015 & 2.838 .273 .074 & 590.584 .744 & $480,59 \%$ & 0 & Tidak Baik \\
\hline 2016 & 2.748 .940 .689 & 564.697 .649 & $486,80 \%$ & 0 & Tidak Baik \\
\hline 2017 & 2.927 .605 .458 & 616.471 .838 & $474,90 \%$ & 0 & Tidak Baik \\
\hline 3. KOPERASI SEGAR INDAH \\
\hline 2015 & 844.095 .013 & 163.149 .129 & $517,38 \%$ & 0 & Tidak Baik \\
\hline 2016 & 822.014 .270 & 131.696 .890 & $624,17 \%$ & 0 & Tidak Baik \\
\hline 2017 & 866.175 .756 & 194.601 .367 & $445,10 \%$ & 0 & Tidak Baik \\
\hline 4. KOPERASI SEJAHTERA SMAN 5 PEKANBARU \\
\hline 2015 & 1.760 .144 .749 & 1.017 .065 .919 & $173,06 \%$ & 50 & Cukup Baik \\
\hline 2016 & 1.840 .103 .207 & 1.092 .851 .775 & $168,38 \%$ & 50 & Cukup Baik \\
\hline 2017 & 1.680 .186 .291 & 941.280 .063 & $178,50 \%$ & 75 & Baik \\
\hline 5. KOPERASI PRIMA BADAN KEPEGAWAIAN DAERAH PROVINSI RIAU & \\
\hline 2015 & 437.498 .895 & 79.054 .602 & $553,41 \%$ & 0 & Tidak Baik \\
\hline 2016 & 451.337 .076 & 82.715 .424 & $545,65 \%$ & 0 & Tidak Baik \\
\hline 2017 & 423.660 .713 & 75.393 .780 & $561,93 \%$ & 0 & Tidak Baik \\
\hline 6. KOPERASI PENGAYOMAN PEGAWAI DEPARTEMEN KEHAKIMAN & \\
\hline
\end{tabular}




\begin{tabular}{|c|c|c|c|c|c|}
\hline Tahun & Aktiva Lancar (Rp) & $\begin{array}{c}\text { Pasiva Lancar } \\
(\text { Rp) }\end{array}$ & Curent Ratio & Nilai & Kriteria \\
\hline 2015 & 1.013 .344 .258 & 495.922 .447 & $204,34 \%$ & 100 & Sangat Baik \\
\hline 2016 & 902.932 .643 & 426.716 .407 & $211,60 \%$ & 100 & Sangat Baik \\
\hline 2017 & 1.123 .755 .872 & 565.128 .486 & $198,85 \%$ & 75 & Baik \\
\hline 7. KP-RI KESUMA NEGERI 1 \\
\hline 2015 & 1.953 .071 .950 & 676.094 .085 & $288,88 \%$ & 50 & Cukup Baik \\
\hline 2016 & 1.876 .319 .553 & 625.495 .938 & $299,97 \%$ & 50 & Cukup Baik \\
\hline 2017 & 2.029 .824 .346 & 726.692 .231 & $279,32 \%$ & 50 & Cukup Baik \\
\hline 8. KOPERASI PEGAWAI LOGISTIK RIAU \\
\hline 2015 & 1.575 .637 .666 & 5.476 .079 .211 & $28,77 \%$ & 0 & Tidak Baik \\
\hline 2016 & 1.536 .089 .382 & 6.330 .857 .380 & $24,26 \%$ & 0 & Tidak Baik \\
\hline 2017 & 1.615 .185 .949 & 4.621 .301 .042 & $34,95 \%$ & 0 & Tidak Baik \\
\hline 9. KOPERASI KORPRI RIAU \\
\hline 2015 & 2.852 .029 .236 & 710.053 .443 & $401,66 \%$ & 0 & Tidak Baik \\
\hline 2016 & 2.906 .059 .671 & 731.688 .335 & $397,17 \%$ & 0 & Tidak Baik \\
\hline 2017 & 2.797 .998 .800 & 688.418 .550 & $406,44 \%$ & 0 & Tidak Baik \\
\hline 10. KPRI BINA TANI & \multicolumn{5}{|l|}{} \\
\hline 2015 & 264.296 .516 & 56.454 .929 & $468,15 \%$ & 0 & Tidak Baik \\
\hline 2016 & 217.136 .556 & 37.429 .458 & $580,12 \%$ & 0 & Tidak Baik \\
\hline 2017 & 311.456 .476 & 75.480 .400 & $412,63 \%$ & 0 & Tidak Baik \\
\hline \multicolumn{7}{|l|}{ Rata-Rata } & $377,05 \%$ & 0 & Tidak Baik \\
\hline
\end{tabular}

Sumber : Data Olahan, 2018.

Berdasarkan Tabel di atas, dapat dilihat bahwa kinerja keuangan dari 10 Koperasi KPRI di Kota Pekanbaru, kurun waktu 2015-2017, terdapat 6 koperasi yang memiliki kinerja tidak baik dengan nilai 0 . Selain itu Koperasi KP-RI Kesuma Negeri 1, juga memiliki nilai yang tetap selama kurun waktu 205-2017 sebesar 50, berada dalam kriteria cukup baik. Sisanya 3 Koperasi memiliki nilai yang berfluktuatif dari tahun ke tahun. Maka dapat disimpulkan bahwa kinerja keuangan koperasi KPRI di Kota Pekanbaru jika ditinjau dari Curent Ratio, dengan nilai rata-rata sebesar $377,05 \%$, berada pada kriteria Tidak Baik

Rata-rata keseluruhan berada pada kriteria Tidak Baik menggambarkan bahwa rasio ini terlalu besar. Hal ini dikarenakan terjadinya penumpukan piutang usaha dalam komponen aktiva lancer, sehingga menunjukkan adanya modal kerja yang tidak efektif, untuk digunakan dalam menjalankan usaha koperasi. Hal ini sejalan dengan penelitian yang dilakukan Rachmawati (2013) bahwa curren ratio berada pada kriteria tidak baik. Namun tidak sejalan dengan penelitian Ilham (2011), bahwa current ratio pada kriteria baik.

\section{Rasio Solvabilitas}

\section{Total Hutang (Kewajiban) Terhadap Asset}

Rasio ini menekankan pentingnya pendanaan utang dengan cara menunjukkan prosentase aktiva yang didukung dengan pendanaan utang. Rasio ini menunjukkan sejauh mana hutang koperasi dapat ditutupi oleh aktiva. Semakin tinggi rasio ini akan semakin sulit bagi perusahaan untuk memperoleh tambahan pinjaman karena dikhawatirkan perusahaan tidak mampu memenuhi utangnnya dengan aktiva yang dimiliki. Perhitungan total hutang (kewajiban) terhadap asset dari laporan keuangan KPRI di Kota Pekanbaru pada Tahun 2015, 2016 dan 2017 dapat dilihat pada Tabel sebagai berikut : 
Tabel 4. Perhitungan Total Hutang (Kewajiban) Terhadap Asset

\begin{tabular}{|c|c|c|c|c|c|}
\hline Tahun & Hutang (Rp) & Asset (Rp) & $\begin{array}{c}\text { Hutang } \\
\text { Terhadap Asset }\end{array}$ & Nilai & Kriteria \\
\hline \multicolumn{6}{|c|}{ 1. KOPERASI SITI PAYUNG } \\
\hline 2015 & 188.042 .860 & 745.666 .557 & $25,22 \%$ & 100 & Sangat Baik \\
\hline 2016 & 333.909 .346 & 870.678 .819 & $38,35 \%$ & 100 & Sangat Baik \\
\hline 2017 & 42.176 .375 & 620.654 .294 & $6,80 \%$ & 100 & Sangat Baik \\
\hline \multicolumn{6}{|c|}{ 2. KOPERASI MAN 2 \& MTsN PEKANBARU } \\
\hline 2015 & 590.584 .744 & 2.847 .240 .340 & $20,74 \%$ & 100 & Sangat Baik \\
\hline 2016 & 564.697 .649 & 2.758 .017 .955 & $20,47 \%$ & 100 & Sangat Baik \\
\hline 2017 & 616.471 .838 & 2.936 .462 .724 & $20,99 \%$ & 100 & Sangat Baik \\
\hline \multicolumn{6}{|c|}{ 3. KOPERASI SEGAR INDAH } \\
\hline 2015 & 163.149 .129 & 979.908 .924 & $16,65 \%$ & 100 & Sangat Baik \\
\hline 2016 & 131.696 .890 & 950.356 .770 & $13,86 \%$ & 100 & Sangat Baik \\
\hline 2017 & 194.601 .367 & 1.009 .461 .077 & $19,28 \%$ & 100 & Sangat Baik \\
\hline \multicolumn{6}{|c|}{ 4. KOPERASI SEJAHTERA SMAN 5 PEKANBARU } \\
\hline 2015 & 1.017 .065 .919 & 1.797 .023 .391 & $56,60 \%$ & 50 & Cukup Baik \\
\hline 2016 & 1.092 .851 .775 & 1.878 .470 .344 & $58,18 \%$ & 50 & Cukup Baik \\
\hline 2017 & 941.280 .063 & 1.715 .576 .438 & $54,87 \%$ & 50 & Cukup Baik \\
\hline \multicolumn{6}{|c|}{ 5. KOPERASI PRIMA BADAN KEPEGAWAIAN DAERAH PROVINSI RIAU } \\
\hline 2015 & 94.887 .910 & 450.203 .520 & $21,08 \%$ & 100 & Sangat Baik \\
\hline 2016 & 114.382 .091 & 465.072 .326 & $24,59 \%$ & 100 & Sangat Baik \\
\hline 2017 & 75.393 .780 & 435.334 .713 & $17,32 \%$ & 100 & Sangat Baik \\
\hline \multicolumn{6}{|c|}{ 6. KOPERASI PENGAYOMAN PEGAWAI DEPARTEMEN KEHAKIMAN } \\
\hline 2015 & 495.922 .447 & 1.013 .344 .258 & $48,94 \%$ & 75 & Baik \\
\hline 2016 & 426.716 .407 & 902.932 .643 & $47,26 \%$ & 75 & Baik \\
\hline 2017 & 565.128 .486 & 1.123 .755 .872 & $50,29 \%$ & 50 & Cukup Baik \\
\hline \multicolumn{6}{|c|}{ 7. KP-RI KESUMA NEGERI 1} \\
\hline 2015 & 676.094 .085 & 1.953 .071 .950 & $34,62 \%$ & 100 & Sangat Baik \\
\hline 2016 & 625.495 .938 & 1.876 .319 .553 & $33,34 \%$ & 100 & Sangat Baik \\
\hline 2017 & 726.692 .231 & 2.029 .824 .346 & $35,80 \%$ & 100 & Sangat Baik \\
\hline \multicolumn{6}{|c|}{ 8. KOPERASI PEGAWAI LOGISTIK RIAU } \\
\hline 2015 & 5.485 .286 .481 & 8.173 .220 .148 & $67,11 \%$ & 25 & Kurang Baik \\
\hline 2016 & 6.349 .271 .920 & 8.970 .098 .114 & $70,78 \%$ & 25 & Kurang Baik \\
\hline 2017 & 4.621 .301 .042 & 7.376 .342 .182 & $62,65 \%$ & 25 & Kurang Baik \\
\hline \multicolumn{6}{|c|}{ 9. KOPERASI KORPRI RIAU } \\
\hline 2015 & 2.710 .053 .498 & 4.610 .139 .220 & $58,78 \%$ & 50 & Cukup Baik \\
\hline 2016 & 2.731 .688 .445 & 4.679 .304 .436 & $58,38 \%$ & 50 & Cukup Baik \\
\hline 2017 & 2.688 .418 .550 & 4.540 .974 .003 & $59,20 \%$ & 50 & Cukup Baik \\
\hline \multicolumn{6}{|c|}{ 10. KPRI BINA TANI } \\
\hline 2015 & 56.454 .929 & 264.427 .516 & $21,35 \%$ & 100 & Sangat Baik \\
\hline 2016 & 37.429 .458 & 217.267 .556 & $17,23 \%$ & 100 & Sangat Baik \\
\hline 2017 & 75.480 .400 & 311.587 .476 & $24,22 \%$ & 100 & Sangat Baik \\
\hline \multicolumn{3}{|c|}{ Rata-Rata } & $36,83 \%$ & 100 & Sanqat Baik \\
\hline
\end{tabular}

Sumber : Data Olahan, 2018.

Berdasarkan Tabel di atas, maka dapat dilihat bahwa kinerja keuangan dari 10 Koperasi KPRI di Kota Pekanbaru pada Tahun 2015-2017, terdapat 6 koperasi yang memiliki kinerja sangat baik dengan nilai 100 , namun ada 2 koperasi yang memiliki nilai cukup baik dengan nilai 
50, selain itu 1 koperasi yang memiliki nilai kurang baik dengan nilai 25, dan ada 1 koperasi yang setiap tahunnya kinerja berubah-ubah yaitu Koperasi Pengayoman Pegawai Departemen Kehakiman dimana pada Tahun 2015 dan 2016 memiliki kinerja baik dengan nilai 75, namun pada Tahun 2015 kinerjanya menurun menjadi cukup baik dengan nilai 50. Maka dapat disimpulkan bahwa kinerja keuangan koperasi KPRI di Kota Pekanbaru jika ditinjau dari total hutang (kewajiban) terhadap asset, dengan nilai rata-rata sebesar $36,83 \%$, berada pada kriteria Sangat Baik.

Rata-rata keseluruhan berada pada kriteria Sangat Baik menggambarkan bahwa mayoritas koperasi mampu mengelola modal sendiri dengan baik, dapat dilihat dari rasio utang yang rendah. Rendahnya Rasio Hutang juga memiliki arti hanya sebagian kecil aset perusahaan yang dibiayai dari Hutang. Namun untuk Koperasi Sejahtera SMAN 5 Pekanbaru, Koperasi Prima Badan Kepegawaian Daerah Provinsi Riau dan Koperasi KORPRI Riau memiliki resiko yang tinggi terkait dengan operasional perusahaan hal ini dikarenakan tingginya rasio utang yang mengindikasikan pembiayaan konservatif dengan kesempatan untuk meminjam di masa depan dengan risiko yang sangat besar.

Hal ini sejalan dengan penelitian yang dilakukan Ilham (2011) bahwa Total Hutang terhadap Asset berada pada kriteria sangat baik. Tidak sejalan dengan penelitian Rachmawati (2013), bahwa Total Hutang terhadap Asset pada kriteria baik.

\section{Total Hutang (Kewajiban) Terhadap Modal Sendiri}

Rasio hutang terhadap modal sendiri merupakan perbandingan antara hutang dan modal sendiri yang dinyatakan dalam prosentase. Rasio ini menunjukkan kemampuan modal sendiri milik koperasi dalam menjamin terbayarnya utang atau kewajiban koperasi. Perhitungan Total Hutang (Kewajiban) Terhadap Modal Sendiri KPRI di Kota Pekanbaru dapat dilihat pada Tabel sebagai berikut :

Tabel 5. Perhitungan Total Hutang (Kewajiban) Terhadap Modal Sendiri

\begin{tabular}{|l|c|c|c|c|c|}
\hline Tahun & Hutang (Rp) & $\begin{array}{c}\text { Modal Sendiri } \\
\text { (Rp) }\end{array}$ & $\begin{array}{c}\text { Hutang Terhadap } \\
\text { Modal Sendiri }\end{array}$ & Nilai & Kriteria \\
\hline 1. KOPERASI SITI PAYUNG \\
\hline 2015 & 188.042 .860 & 557.623 .696 & $33,72 \%$ & 100 & Sangat Baik \\
\hline 2016 & 333.909 .346 & 536.769 .473 & $62,21 \%$ & 100 & Sangat Baik \\
\hline 2017 & 42.176 .375 & 578.477 .919 & $7,29 \%$ & 100 & Sangat Baik \\
\hline 2. KOPERASI MAN 2 \& MTsN PEKANBARU \\
\hline 2015 & 590.584 .744 & 2.256 .655 .597 & $26,17 \%$ & 100 & Sangat Baik \\
\hline 2016 & 564.697 .649 & 2.193 .320 .307 & $25,75 \%$ & 100 & Sangat Baik \\
\hline 2017 & 616.471 .838 & 2.319 .990 .886 & $26,57 \%$ & 100 & Sangat Baik \\
\hline 3. KOPERASI SEGAR INDAH & \multicolumn{5}{|l}{} \\
\hline 2015 & 163.149 .129 & 816.759 .795 & $19,98 \%$ & 100 & Sangat Baik \\
\hline 2016 & 131.696 .890 & 818.659 .879 & $16,09 \%$ & 100 & Sangat Baik \\
\hline 2017 & 194.601 .367 & 814.859 .710 & $23,88 \%$ & 100 & Sangat Baik \\
\hline 4. KOPERASI SEJAHTERA SMAN 5 PEKANBARU \\
\hline 2015 & 1.017 .065 .919 & 779.957 .472 & $130,40 \%$ & 50 & Cukup Baik \\
\hline 2016 & 1.092 .851 .775 & 785.618 .569 & $139,11 \%$ & 50 & Cukup Baik \\
\hline 2017 & 941.280 .063 & 774.296 .375 & $121,57 \%$ & 50 & Cukup Baik \\
\hline 5. KOPERASI PRIMA BADAN KEPEGAWAIAN DAERAH PROVINSI RIAU & \\
\hline 2015 & 94.887 .910 & 355.315 .610 & $26,71 \%$ & 100 & Sangat Baik \\
\hline
\end{tabular}




\begin{tabular}{|c|c|c|c|c|c|}
\hline Tahun & Hutang (Rp) & $\begin{array}{l}\text { Modal Sendiri } \\
\text { (Rp) }\end{array}$ & $\begin{array}{l}\text { Hutang Terhadap } \\
\text { Modal Sendiri }\end{array}$ & Nilai & Kriteria \\
\hline 2016 & 114.382 .091 & 350.690 .235 & $32,62 \%$ & 100 & Sangat Baik \\
\hline 2017 & 75.393 .780 & 359.940 .985 & $20,95 \%$ & 100 & Sangat Baik \\
\hline \multicolumn{6}{|c|}{ 6. KOPERASI PENGAYOMAN PEGAWAI DEPARTEMEN KEHAKIMAN } \\
\hline 2015 & 495.922 .447 & 517.421 .811 & $95,84 \%$ & 75 & Baik \\
\hline 2016 & 426.716 .407 & 476.216 .236 & $89,61 \%$ & 75 & Baik \\
\hline 2017 & 565.128 .486 & 558.627 .386 & $101,16 \%$ & 50 & Cukup Baik \\
\hline \multicolumn{6}{|c|}{ 7. KP-RI KESUMA NEGERI 1} \\
\hline 2015 & 676.094 .085 & 1.276 .977 .865 & $52,94 \%$ & 100 & Sangat Baik \\
\hline 2016 & 625.495 .938 & 1.250 .823 .615 & $50,01 \%$ & 100 & Sangat Baik \\
\hline 2017 & 726.692 .231 & 1.303 .132 .115 & $55,77 \%$ & 100 & Sangat Baik \\
\hline \multicolumn{6}{|c|}{ 8. KOPERASI PEGAWAI LOGISTIK RIAU } \\
\hline 2015 & 5.485.286.481 & 2.687 .433 .666 & $204,11 \%$ & 0 & Tidak Baik \\
\hline 2016 & 6.349.271.920 & 2.620.826.192 & $242,26 \%$ & 0 & Tidak Baik \\
\hline 2017 & 4.621 .301 .042 & 2.754 .041 .140 & $167,80 \%$ & 25 & Kurang Baik \\
\hline \multicolumn{6}{|c|}{ 9. KOPERASI KORPRI RIAU } \\
\hline 2015 & 2.710 .053 .498 & 1.900 .085 .777 & $142,63 \%$ & 50 & Cukup Baik \\
\hline 2016 & 2.731 .688 .445 & 1.852 .555 .453 & $147,46 \%$ & 50 & Cukup Baik \\
\hline 2017 & 2.688 .418 .550 & 1.947 .616 .101 & $138,04 \%$ & 50 & Cukup Baik \\
\hline \multicolumn{6}{|c|}{ 10. KPRI BINA TANI } \\
\hline 2015 & 56.454 .929 & 207.972 .587 & $27,15 \%$ & 100 & Sangat Baik \\
\hline 2016 & 37.429 .458 & 179.838 .098 & $20,81 \%$ & 100 & Sangat Baik \\
\hline 2017 & 75.480 .400 & 236.107 .076 & $31,97 \%$ & 100 & Sangat Baik \\
\hline \multicolumn{3}{|c|}{ Rata-Rata } & $76,02 \%$ & 75 & Baik \\
\hline
\end{tabular}

Sumber : Data Olahan, 2018.

Berdasarkan Tabel di atas, maka dapat dilihat bahwa kinerja keuangan dari 10 Koperasi KPRI di Kota Pekanbaru selama kurun waktu 2015-2017, terdapat 6 koperasi yang memiliki kinerja sangat baik dengan nilai 100, serta 2 koperasi yang memiliki nilai cukup baik dengan niali 50, selain itu ada Koperasi Pengayoman Pegawai Departemen Kehakiman pada Tahun 2015 dan 2016 memiliki kinerja yang baik dengan nilai 75 namun pada Tahun 2017 kinerjanya menurun menjadi cukup baik dengan nilai 50 . Sedangkan koperasi yang memiliki kinerja paling rendah yaitu Koperasi Pegawai Logistik Riau dimana pada tahun 2015 dan 2016 memiliki nilai 0 (tidak baik), Tahun 2017memiliki nilai 25 (kurang baik). Maka dapat disimpulkan bahwa kinerja keuangan koperasi KPRI di Kota Pekanbaru jika ditinjau dari total Hutang (kewajiban) terhadap modal sendiri, dengan nilai rata-rata sebesar $76,02 \%$, berada pada kriteria Baik.

Rata-rata keseluruhan berada pada kriteria Baik menggambarkan bahwa mayoritas koperasi memiliki kebijakan harus memiliki utang yang tidak lebih besar dari modal yang dimiliknya. Karna semakin kecil rasio ini akan memperbaiki keadaan koperasi, artinya semakin kecil utang yang dimiliki maka semakin aman. Namun masih ada koperasi yang sangat beresiko seperti Koperasi Sejahtera SMAN 5 Pekanbaru, KP-RI Kesuma Negeri 1, dan rasio utangnya sangat tinggi yaitu Koperasi Pegawai Logistik, dimana dalam 3 tahun terakhir nilai berkisaran 0 25 dengan kriteria tidak baik - kurang baik, koperasi ini sangat memerlukan perbaikan yang sangat intensif untuk mengatasi permasalahan ini.

Sejalan dengan penelitian Huda dkk (2017) bahwa hasil penelitian Total Hutang (Kewajiban) Terhadap Modal Sendiri berada pada kriteria baik. Namun tidak sejalan dengan 
penelitian Erindai (2015), bawha hasil penelitian Total Hutang (Kewajiban) Terhadap Modal Sendiri berada pada kriteria sangat baik.

\section{Rasio Profitabilitas/ Rentabilitas}

\section{Kemampuan Menghasilan Laba (Net Profit Margin)}

Rasio ini digunakan untuk mengetahui kemampuan KPRI di Kota Pekanbaru dalam menghasilkan laba, yang dapat dilihat pada Tabel sebagai berikut :

Tabel 6. Perhitungan Net Profit Margin

\begin{tabular}{|c|c|c|c|c|c|}
\hline Tahun & SHU (Rp) & $\begin{array}{l}\text { Pasiva Lancar } \\
\text { (Rp) }\end{array}$ & Net Profit Margin & Nilai & Kriteria \\
\hline \multicolumn{6}{|c|}{ 1. KOPERASI SITI PAYUNG } \\
\hline 2015 & 26.902 .907 & 188.042 .860 & $14,31 \%$ & 75 & Baik \\
\hline 2016 & 26.043 .313 & 333.909 .346 & $7,80 \%$ & 50 & Cukup Baik \\
\hline 2017 & 27.762 .500 & 42.176 .373 & $65,82 \%$ & 100 & Sangat Baik \\
\hline \multicolumn{6}{|c|}{ 2. KOPERASI MAN 2 \& MTsN PEKANBARU } \\
\hline 2015 & 56.508 .612 & 590.584 .744 & $9,57 \%$ & 75 & Baik \\
\hline 2016 & 50.002 .278 & 564.697 .649 & $8,85 \%$ & 75 & Baik \\
\hline 2017 & 63.014 .946 & 616.471 .838 & $10,22 \%$ & 75 & Baik \\
\hline \multicolumn{6}{|c|}{ 3. KOPERASI SEGAR INDAH } \\
\hline 2015 & 35.180 .570 & 163.149 .129 & $21,56 \%$ & 100 & Sangat Baik \\
\hline 2016 & 41.879 .140 & 131.696 .890 & $31,80 \%$ & 100 & Sangat Baik \\
\hline 2017 & 28.482 .000 & 194.601 .367 & $14,64 \%$ & 100 & Sangat Baik \\
\hline \multicolumn{6}{|c|}{ 4. KOPERASI SEJAHTERA SMAN 5 PEKANBARU } \\
\hline 2015 & 175.543 .653 & 1.017.065.919 & $17,26 \%$ & 100 & Sangat Baik \\
\hline 2016 & 214.617 .871 & 1.092 .851 .775 & $19,64 \%$ & 100 & Sangat Baik \\
\hline 2017 & 136.469 .435 & 941.280 .063 & $14,50 \%$ & 75 & Baik \\
\hline \multicolumn{6}{|c|}{ 5. KOPERASI PRIMA BADAN KEPEGAWAIAN DAERAH PROVINSI RIAU } \\
\hline 2015 & 10.519 .557 & 79.054 .602 & $13,31 \%$ & 75 & Baik \\
\hline 2016 & 9.478 .364 & 82.715 .424 & $11,46 \%$ & 75 & Baik \\
\hline 2017 & 11.560 .750 & 75.393 .780 & $15,33 \%$ & 100 & Sangat Baik \\
\hline \multicolumn{6}{|c|}{ 6. KOPERASI PENGAYOMAN PEGAWAI DEPARTEMEN KEHAKIMAN } \\
\hline 2015 & 129.909 .875 & 495.922 .447 & $26,20 \%$ & 100 & Sangat Baik \\
\hline 2016 & 117.221 .000 & 426.716 .407 & $27,47 \%$ & 100 & Sangat Baik \\
\hline 2017 & 142.598 .750 & 565.128 .486 & $25,23 \%$ & 100 & Sangat Baik \\
\hline \multicolumn{6}{|c|}{ 7. KP-RI KESUMA NEGERI 1} \\
\hline 2015 & 213.138 .850 & 676.094 .085 & $31,53 \%$ & 100 & Sangat Baik \\
\hline 2016 & 217.561 .200 & 625.495 .938 & $34,78 \%$ & 100 & Sangat Baik \\
\hline 2017 & 208.716 .500 & 726.692 .231 & $28,72 \%$ & 100 & Sangat Baik \\
\hline \multicolumn{6}{|c|}{ 8. KOPERASI PEGAWAI LOGISTIK RIAU } \\
\hline 2015 & 493.905 .005 & 5.476 .079 .211 & $9,02 \%$ & 75 & Baik \\
\hline 2016 & 615.331 .913 & 6.330 .857 .380 & $9,72 \%$ & 75 & Baik \\
\hline 2017 & 372.478 .096 & 4.621 .301 .042 & $8,06 \%$ & 75 & Baik \\
\hline \multicolumn{6}{|c|}{ 9. KOPERASI KORPRI RIAU } \\
\hline 2015 & 113.243 .447 & 710.053 .443 & $15,95 \%$ & 100 & Sangat Baik \\
\hline 2016 & 169.834 .270 & 731.688 .335 & $23,21 \%$ & 100 & Sangat Baik \\
\hline 2017 & 56.652 .623 & 688.418 .550 & $8,23 \%$ & 75 & Baik \\
\hline \multicolumn{6}{|c|}{ 10. KPRI BINA TANI } \\
\hline 2015 & 31.614 .719 & 56.454 .929 & $56,00 \%$ & 100 & Sangat Baik \\
\hline
\end{tabular}




\begin{tabular}{|c|c|c|c|c|c|}
\hline Tahun & SHU (Rp) & $\begin{array}{l}\text { Pasiva Lancar } \\
\text { (Rp) }\end{array}$ & Net Profit Margin & Nilai & Kriteria \\
\hline 2016 & 29.294 .037 & 37.429 .458 & $78,26 \%$ & 100 & Sangat Baik \\
\hline 2017 & 33.935 .400 & 75.480 .400 & $44,96 \%$ & 100 & Sangat Baik \\
\hline \multicolumn{3}{|c|}{ Rata-Rata } & $23,45 \%$ & 100 & Sangat Baik \\
\hline
\end{tabular}

Sumber : Data Olahan, 2018.

Berdasarkan Tabel di atas, dapat dilihat bahwa dari 10 koperasi KPRI di Kota Pekanbaru yang kinerjanya tidak mengalami penurunan atau kenaikan (tetap) dalam jangka waktu 3 tahun ada 4 koperasi, dan 6 koperasi memiliki kinerja yang berfluktuatif. Selain itu kinerja yang dimiliki koperasi beraneka ragam yaitu berkisaran 50-100, dimana hanya Koperasi Siti Payung yang memiliki kinerja Cukup Baik dengan nilai 50 yaitu pada Tahun 2016. Maka dapat disimpulkan bahwa kinerja keuangan Koperasi KPRI di Kota Pekanbaru jika ditinjau dari Net Profit Margin,dengan nilai rata-rata sebesar 23,45\%, berada pada kriteria Sangat Baik.

Rata-rata keseluruhan berada pada kriteria Sangat Baik menggambarkan bahwa mayoritas koperasi mampu untuk menghasilkan laba tinggi pada tingkat penjualan tertentu. Hal ini dapat dilihat dari meingkatkanya penerimaan piutang serta lancarnya pembayaran pinjamana.

Sejalan dengan penelitian Sari dan Mahmudah (2017), bahwa hasil penelitian Net Profit Margin berada pada kriteria sangat baik. Namun tidak sejalan dengan penelitian Rachmawati (2013) dan Ilham (2011), bahwa hasil penelitian Net Profit Margin berada pada kriteria baik.

\section{Return On Asset (ROA)}

Tabel 7. Perhitungan Return On Asset (ROA)

\begin{tabular}{|l|c|c|c|c|c|}
\hline Tahun & SHU (Rp) & Asset (Rp) & $\begin{array}{c}\text { Return On Asset } \\
(\text { ROA })\end{array}$ & Nilai & Kriteria \\
\hline 1. KOPERASI SITI PAYUNG \\
\hline 2015 & 26.902 .907 & 745.666 .557 & $3,61 \%$ & 50 & Cukup Baik \\
\hline 2016 & 26.043 .313 & 870.678 .819 & $2,99 \%$ & 25 & Kurang Baik \\
\hline 2017 & 27.762 .500 & 620.654 .294 & $4,47 \%$ & 50 & Cukup Baik \\
\hline 2. KOPERASI MAN 2 \& MTsN PEKANBARU \\
\hline 2015 & 56.508 .612 & 2.847 .240 .340 & $1,98 \%$ & 25 & Kurang Baik \\
\hline 2016 & 50.002 .278 & 2.758 .017 .955 & $1,81 \%$ & 25 & Kurang Baik \\
\hline 2017 & 63.014 .946 & 2.936 .462 .724 & $2,15 \%$ & 25 & Kurang Baik \\
\hline 3. KOPERASI SEGAR INDAH \\
\hline 2015 & 35.180 .570 & 979.908 .924 & $3,59 \%$ & 50 & Cukup Baik \\
\hline 2016 & 41.879 .140 & 950.356 .770 & $4,41 \%$ & 50 & Cukup Baik \\
\hline 2017 & 28.482 .000 & 1.009 .461 .077 & $2,82 \%$ & 25 & Kurang Baik \\
\hline 4. KOPERASI SEJAHTERA SMAN 5 PEKANBARU \\
\hline 2015 & 175.543 .653 & 1.797 .023 .391 & $9,77 \%$ & 75 & Baik \\
\hline 2016 & 214.617 .871 & 1.878 .470 .344 & $11,43 \%$ & 100 & Sangat Baik \\
\hline 2017 & 136.469 .435 & 1.715 .576 .438 & $7,95 \%$ & 75 & Baik \\
\hline 5. KOPERASI PRIMA BADAN KEPEGAWAIAN DAERAH PROVINSI RIAU & \\
\hline 2015 & 10.519 .557 & 450.203 .520 & $2,34 \%$ & 25 & Kurang Baik \\
\hline 2016 & 9.478 .364 & 465.072 .326 & $2,04 \%$ & 25 & Kurang Baik \\
\hline 2017 & 11.560 .750 & 435.334 .713 & $2,66 \%$ & 25 & Kurang Baik \\
\hline 6. KOPERASI PENGAYOMAN PEGAWAI DEPARTEMEN KEHAKIMAN \\
\hline 2015 & 129.909 .875 & 1.013 .344 .258 & $12,82 \%$ & 100 & Sangat Baik \\
\hline
\end{tabular}




\begin{tabular}{|c|c|c|c|c|c|}
\hline Tahun & SHU (Rp) & Asset (Rp) & $\begin{array}{c}\text { Return On Asset } \\
\text { (ROA) }\end{array}$ & Nilai & Kriteria \\
\hline 2016 & 117.221 .000 & 902.932 .643 & $12,98 \%$ & 100 & Sangat Baik \\
\hline 2017 & 142.598 .750 & 1.123 .755 .872 & $12,69 \%$ & 100 & Sangat Baik \\
\hline \multicolumn{6}{|c|}{ 7. KP-RI KESUMA NEGERI 1} \\
\hline 2015 & 213.138 .850 & 1.953.071.950 & $10,91 \%$ & 100 & Sangat Baik \\
\hline 2016 & 217.561 .200 & 1.876 .319 .553 & $11,60 \%$ & 100 & Sangat Baik \\
\hline 2017 & 208.716 .500 & 2.029 .824 .346 & $10,28 \%$ & 100 & Sangat Baik \\
\hline \multicolumn{6}{|c|}{ 8. KOPERASI PEGAWAI LOGISTIK RIAU } \\
\hline 2015 & 493.905 .005 & 8.173 .220 .148 & $6,04 \%$ & 50 & Cukup Baik \\
\hline 2016 & 615.331 .913 & 8.970 .098 .114 & $6,86 \%$ & 50 & Cukup Baik \\
\hline 2017 & 372.478 .096 & 7.376.342.182 & $5,05 \%$ & 50 & Cukup Baik \\
\hline \multicolumn{6}{|c|}{ 9. KOPERASI KORPRI RIAU } \\
\hline 2015 & 113.243 .447 & 4.610 .139 .220 & $2,46 \%$ & 25 & Kurang Baik \\
\hline 2016 & 169.834 .270 & 4.540.974.003 & $3,63 \%$ & 50 & Cukup Baik \\
\hline 2017 & 56.652 .623 & 4.679 .304 .436 & $1,25 \%$ & 25 & Kurang Baik \\
\hline \multicolumn{6}{|c|}{ 10. KPRI BINA TANI } \\
\hline 2015 & 31.614 .719 & 264.427 .516 & $11,96 \%$ & 100 & Sangat Baik \\
\hline 2016 & 29.294 .037 & 217.267 .556 & $13,48 \%$ & 100 & Sangat Baik \\
\hline 2017 & 33.935 .400 & 311.587 .476 & $10,89 \%$ & 100 & Sangat Baik \\
\hline \multicolumn{3}{|c|}{ Rata-Rata } & $6,56 \%$ & 50 & Cukup Baik \\
\hline
\end{tabular}

Sumber : Data Olahan, 2018.

Berdasarkan Tabel di atas, dapat dilihat bahwa dari 10 Koperasi KPRI di Kota Pekanbaru 6 diantaranya memiliki kinerja di bawah cukup baik dengan niali $\leq 50$, dan 4 diantaranya berada pada kinerja sangat baik dengan nilai $\geq 75$. Maka dapat disimpulkan bahwa kinerja keuangan Koperasi KPRI di Kota Pekanbaru jika ditinjau dari Retrun On Asset, dengan nilai rata-rata sebesar $6,56 \%$, berada pada kriteria Cukup Baik.

Rata-rata keseluruhan berada pada kriteria Cukup Baik menggambarkan bahwa mayoritas koperasi belum mampu untuk menghasilkan laba dengan mengandalkan semua aktiva yang dimiliki. Hal ini dikarenakan koperasi belum dalam menggunakan secara maksimal segala sumber daya yang dimiliki, sehingga belum mampu merencanakan untuk jangka panjang akan menjadi apa koperasi tersebut dengan sumber daya yang telah dimiliki.

Berbeda dengan penelitian yang dilakukan Rachmawati (2013) bahwa hasil penelitian menunjukkan Retrun On Asset berada pada kriteria baik. Penelitian Bae (2010), bahwa hasil penelitian menunjukkan Retrun On Asset berada pada kriteria kurang baik.

\section{Rentabilitas Modal Sendiri}

Tabel 8. Perhitungan Rentabilitas Modal Sendiri

\begin{tabular}{|l|c|c|c|c|c|}
\hline Tahun & SHU (Rp) & $\begin{array}{c}\text { Modal Sendiri } \\
(\mathrm{Rp})\end{array}$ & $\begin{array}{c}\text { Rentabilitas } \\
\text { Modal Sendiri }\end{array}$ & Nilai & Kriteria \\
\hline 1. KOPERASI SITI PAYUNG \\
\hline 2015 & 26.902 .907 & 557.623 .696 & $4,82 \%$ & 25 & Kurang Baik \\
\hline 2016 & 26.043 .313 & 536.769 .473 & $4,85 \%$ & 25 & Kurang Baik \\
\hline 2017 & 27.762 .500 & 578.477 .919 & $4,80 \%$ & 25 & Kurang Baik \\
\hline 2. KOPERASI MAN 2 \& MTsN PEKANBARU \\
\hline 2015 & 56.508 .612 & 2.256 .655 .597 & $2,50 \%$ & 0 & Tidak Baik \\
\hline
\end{tabular}




\begin{tabular}{|c|c|c|c|c|c|}
\hline Tahun & SHU (Rp) & $\begin{array}{l}\text { Modal Sendiri } \\
\text { (Rp) }\end{array}$ & $\begin{array}{c}\text { Rentabilitas } \\
\text { Modal Sendiri }\end{array}$ & Nilai & Kriteria \\
\hline 2016 & 50.002 .278 & 2.193 .320 .307 & $2,28 \%$ & 0 & Tidak Baik \\
\hline 2017 & 63.014 .946 & 2.319 .990 .886 & $2,27 \%$ & 0 & Tidak Baik \\
\hline \multicolumn{6}{|c|}{ 3. KOPERASI SEGAR INDAH } \\
\hline 2015 & 35.180 .570 & 816.759 .795 & $4,31 \%$ & 25 & Kurang Baik \\
\hline 2016 & 41.879 .140 & 818.659 .879 & $5,12 \%$ & 25 & Kurang Baik \\
\hline 2017 & 28.482 .000 & 814.859 .710 & $3,50 \%$ & 25 & Kurang Baik \\
\hline \multicolumn{6}{|c|}{ 4. KOPERASI SEJAHTERA SMAN 5 PEKANBARU } \\
\hline 2015 & 175.543 .653 & 779.957 .472 & $22,51 \%$ & 100 & Sangat Baik \\
\hline 2016 & 214.617 .871 & 785.618 .569 & $27,32 \%$ & 100 & Sangat Baik \\
\hline 2017 & 136.469 .435 & 774.296 .375 & $17,62 \%$ & 75 & Baik \\
\hline \multicolumn{6}{|c|}{ 5. KOPERASI PRIMA BADAN KEPEGAWAIAN DAERAH PROVINSI RIAU } \\
\hline 2015 & 10.519 .557 & 355.315 .610 & $2,96 \%$ & 0 & Tidak Baik \\
\hline 2016 & 9.478 .364 & 350.690 .235 & $2,70 \%$ & 0 & Tidak Baik \\
\hline 2017 & 11.560 .750 & 359.940 .985 & $3,21 \%$ & 25 & Kurang Baik \\
\hline \multicolumn{6}{|c|}{ 6. KOPERASI PENGAYOMAN PEGAWAI DEPARTEMEN KEHAKIMAN } \\
\hline 2015 & 129.909 .875 & 517.421 .811 & $25,11 \%$ & 100 & Sangat Baik \\
\hline 2016 & 117.221 .000 & 476.216 .236 & $24,62 \%$ & 100 & Sangat Baik \\
\hline 2017 & 142.598 .750 & 558.627 .386 & $25,53 \%$ & 100 & Sangat Baik \\
\hline \multicolumn{6}{|c|}{ 7. KP-RI KESUMA NEGERI 1} \\
\hline 2015 & 213.138 .850 & 1.276 .977 .865 & $16,69 \%$ & 75 & Baik \\
\hline 2016 & 217.561 .200 & 1.250 .823 .615 & $17,39 \%$ & 75 & Baik \\
\hline 2017 & 208.716 .500 & 1.303 .132 .115 & $16,02 \%$ & 75 & Baik \\
\hline \multicolumn{6}{|c|}{ 8. KOPERASI PEGAWAI LOGISTIK RIAU } \\
\hline 2015 & 493.905 .005 & 2.687 .433 .666 & $18,38 \%$ & 75 & Baik \\
\hline 2016 & 615.331 .913 & 2.620 .826 .192 & $23,48 \%$ & 100 & Sangat Baik \\
\hline 2017 & 372.478 .096 & 2.754 .041 .140 & $13,52 \%$ & 50 & Cukup Baik \\
\hline \multicolumn{6}{|c|}{ 9. KOPERASI KORPRI RIAU } \\
\hline 2015 & 113.243 .447 & 1.900 .085 .777 & $5,96 \%$ & 25 & Kurang Baik \\
\hline 2016 & 169.834 .270 & 1.947 .616 .101 & $9,17 \%$ & 50 & Cukup Baik \\
\hline 2017 & 56.652 .623 & 1.852 .555 .453 & $2,91 \%$ & 0 & Tidak Baik \\
\hline \multicolumn{6}{|c|}{ 10. KPRI BINA TANI } \\
\hline 2015 & 31.614 .719 & 207.972.587 & $15,20 \%$ & 75 & Baik \\
\hline 2016 & 29.294 .037 & 179.838 .098 & $16,29 \%$ & 75 & Baik \\
\hline 2017 & 33.935 .400 & 236.107 .076 & $14,37 \%$ & 50 & Cukup Baik \\
\hline \multicolumn{3}{|c|}{ Rata-Rata } & $11,86 \%$ & 50 & Cukup Baik \\
\hline
\end{tabular}

Sumber : Data Olahan, 2018.

Berdasakran Tabel di atas, dapat dilihat bahwa dari 10 koperasi KPRI di Kota Pekanbaru, kurun waktu 2015-2017, hanya Koperasi Pengayoman Pegawai Departemen Kehakiman yang memiliki kinerja sangat baik dengan nilai 100, selain itu KP-RI Kesuma Negeri 1 yang memiliki kinerja baik dengan niali 75 . Jika di tinjau dari kinerja yang terendah pertama berada pada Koperasi MAN 2 \& MTsN Pekanbaru yang memiliki kriteria tidak baik dengan nilai 0 . Maka dapat disimpulkan bahwa kinerja keuangan Koperasi KPRI di Kota Pekanbaru jika ditinjau dari Rentabilitas Modal Sendiri, dengan nilai rata-rata sebesar $11,86 \%$, berada pada kriteria Cukup Baik.

Rata-rata keseluruhan berada pada kriteria Cukup Baik menggambarkan bahwa mayoritas koperasi belum mampu untuk menghasilkan laba yang berasal dari modal sendiri. Hal 
ini dikarenakan koperasi sebagian besar modal masih ketergantungan dengan hutang, bukan berasa dari SKHU.

Namun tidak sejalan dengan penelitian Erindani (2015) bahwa hasil penelitian rentabilitas modal sendiri berada pada kriteria sangat baik. Penelitian Rachmawati (2013) bahwa hasil penelitian rentabilitas modal sendiri berada pada kriteria baik.

\section{Rasio Aktivitas}

Rasio aktivitas yaitu terdiri dari pendapatan atas rata-rata piutang (tahun sebelumnya dan tahun saat ini), dan volume usaha (pendapatan) terhadap asset, yang dapat dilihat sebagai berikut :

\section{Perputaran Piutang}

Tabel 9. Perhitungan Perputaran Piutang

\begin{tabular}{|c|c|c|c|c|c|}
\hline Tahun & Pendapatan (Rp) & $\begin{array}{c}\text { Rata-Rata } \\
\text { Piutang (Rp) }\end{array}$ & $\begin{array}{c}\text { Perputaran } \\
\text { Piutang }\end{array}$ & Nilai & Kriteria \\
\hline \multicolumn{6}{|c|}{ 1. KOPERASI SITI PAYUNG } \\
\hline 2015 & 201.722.539 & 612.887 .955 & 32,91 Kali & 100 & Sangat Baik \\
\hline 2016 & 65.034 .447 & 651.791 .023 & 9,98 Kali & 50 & Cukup Baik \\
\hline 2017 & 338.410 .631 & 573.984 .886 & 58,96 Kali & 100 & Sangat Baik \\
\hline \multicolumn{6}{|c|}{ 2. KOPERASI MAN 2 \& MTsN PEKANBARU } \\
\hline 2015 & 254.255 .430 & 2.787 .135 .227 & 9,12 Kali & 50 & Cukup Baik \\
\hline 2016 & 247.465 .460 & 2.765 .464 .046 & 8,95 Kali & 50 & Cukup Baik \\
\hline 2017 & 261.045 .400 & 2.808 .806 .408 & 9,29 Kali & 50 & Cukup Baik \\
\hline \multicolumn{6}{|c|}{ 3. KOPERASI SEGAR INDAH } \\
\hline 2015 & 47.389 .500 & 814.996 .990 & 5,81 Kali & 0 & Tidak Baik \\
\hline 2016 & 42.840 .000 & 809.046 .985 & 5,30 Kali & 0 & Tidak Baik \\
\hline 2017 & 51.939 .000 & 820.946 .995 & 6,33 Kali & 25 & Kurang Baik \\
\hline \multicolumn{6}{|c|}{ 4. KOPERASI SEJAHTERA SMAN 5 PEKANBARU } \\
\hline 2015 & 1.206.544.377 & 1.708.320.857 & 70,63 Kali & 100 & Sangat Baik \\
\hline 2016 & 24.698 .000 & 1.755.539.614 & 1,41 Kali & 0 & Tidak Baik \\
\hline 2017 & 2.388 .390 .753 & 1.661 .102 .100 & 143,78 Kali & 100 & Sangat Baik \\
\hline \multicolumn{6}{|c|}{ 5. KOPERASI PRIMA BADAN KEPEGAWAIAN DAERAH PROVINSI RIAU } \\
\hline 2015 & 25.811 .000 & 248.553 .620 & 10,38 Kali & 75 & Baik \\
\hline 2016 & 21.622 .000 & 244.914 .636 & 8,83 Kali & 50 & Cukup Baik \\
\hline 2017 & 30.000 .000 & 252.192 .604 & 11,90 Kali & 75 & Baik \\
\hline \multicolumn{6}{|c|}{ 6. KOPERASI PENGAYOMAN PEGAWAI DEPARTEMEN KEHAKIMAN } \\
\hline 2015 & 142.823 .750 & 955.745 .313 & 14,94 Kali & 100 & Sangat Baik \\
\hline 2016 & 133.240 .000 & 926.051 .875 & 14,39 Kali & 100 & Sangat Baik \\
\hline 2017 & 152.407 .500 & 985.438 .750 & 15,47 Kali & 100 & Sangat Baik \\
\hline \multicolumn{6}{|c|}{ 7. KP-RI KESUMA NEGERI 1} \\
\hline 2015 & 246.145 .000 & 1.158 .995 .313 & 21, 24 Kali & 100 & Sangat Baik \\
\hline 2016 & 252.225 .000 & 1.160 .978 .125 & 21,73 Kali & 100 & Sangat Baik \\
\hline 2017 & 240.065 .000 & 1.157 .012 .500 & 20,74 Kali & 100 & Sangat Baik \\
\hline \multicolumn{6}{|c|}{ 8. KOPERASI PEGAWAI LOGISTIK RIAU } \\
\hline 2015 & 3.595 .737 .771 & 751.244 .747 & 478,64 Kali & 100 & Sangat Baik \\
\hline 2016 & 3.576 .578 .000 & 724.712 .135 & 493,52 Kali & 100 & Sangat Baik \\
\hline 2017 & 3.614 .897 .542 & 777.777 .358 & 464,77 Klai & 100 & Sangat Baik \\
\hline \multicolumn{6}{|c|}{ 9. KOPERASI KORPRI RIAU } \\
\hline 2015 & 548.960 .270 & 1.865 .491 .856 & 29,43 Kali & 100 & Sangat Baik \\
\hline
\end{tabular}




\begin{tabular}{|c|c|c|c|c|c|}
\hline Tahun & Pendapatan (Rp) & $\begin{array}{l}\text { Rata-Rata } \\
\text { Piutang (Rp) }\end{array}$ & $\begin{array}{l}\text { Perputaran } \\
\text { Piutang }\end{array}$ & Nilai & Kriteria \\
\hline 2016 & 508.798 .980 & 1.877 .586 .688 & 27,10 Kali & 100 & Sangat Baik \\
\hline 2017 & 589.121 .560 & 1.853 .397 .025 & 31,79 Kali & 100 & Sangat Baik \\
\hline \multicolumn{6}{|c|}{ 10. KPRI BINA TANI } \\
\hline 2015 & 47.458 .700 & 108.340 .908 & 43,80 Kali & 100 & Sangat Baik \\
\hline 2016 & 45.700 .000 & 106.362 .089 & 42,97 Kali & 100 & Sangat Baik \\
\hline 2017 & 49.217 .400 & 110.319 .726 & 44,61 Kali & 100 & Sangat Baik \\
\hline \multicolumn{3}{|c|}{ Rata-Rata } & 71,96 Kali & 100 & Sangat Baik \\
\hline
\end{tabular}

Sumber : Data Olahan, 2018.

Berdasarkan Tabel di atas, dapat dilihat bahwa dari 10 Koperasi KPRI di Kota Pekanbaru, dalam kurun waktu 2015-2017, hanya terdapat 5koperasi yang memiliki kinerja tetap dan berada dalam kriteria sangat baik dengn nilai 100 , dan sisanya 5 koperasi memiliki kinerja yang berfluktuatif dari setiap tahun. dimana koperasi yang memiliki kinerja terjelek jika dilihat dari Perputaran Piutang yaitu Koperasi Segar Indah dengan niali pada Tahun 2015 sebesar 0, 2016 sebesar 0 dan 2017 sebesar 25. Maka dapat disimpulkan bahwa kinerja keuangan Koperasi KPRI di Kota Pekanbaru jika ditinjau dari Perputaran Piutang, dengan nilai rata-rata sebesar 71,96 Kali, berada pada kriteria Sangat Baik.

Rata-rata keseluruhan berada pada kriteria Sangat Baik menggambarkan bahwa mayoritas koperasi telah mampu untuk lebih efisien dalam mengumpulkan piutang, maka semakin tinggi Rasio perputaran piutang akan lebih menguntungkan. Hal ini dapat dilihat dari kemampuan koperasi dalam mengumpulkan piutang dan semakin tingginya partisipasi peminjam untuk membayar. Sejalan dengan penelitian Habibah (2013) bahwa hasil penelitian menunjukkan perhitungan perputaran piutang berada pada kriteria sangat baik.

\section{Perputaran Aktiva}

Tabel 10. Perhitungan Perputaran Aktiva

\begin{tabular}{|l|c|c|c|c|c|}
\hline Tahun & Pendapatan (Rp) & Asset (Rp) & $\begin{array}{c}\text { Perputaran } \\
\text { Aktiva }\end{array}$ & Nilai & Kriteria \\
\hline 1. KOPERASI SITI PAYUNG \\
\hline 2015 & 201.722 .539 & 745.666 .557 & 27,05 Kali & 100 & Sangat Baik \\
\hline 2016 & 65.034 .447 & 870.678 .819 & 7,47 Kali & 100 & Sangat Baik \\
\hline 2017 & 338.410 .631 & 620.654 .294 & 54,52 Kali & 100 & Sangat Baik \\
\hline 2. KOPERASI MAN 2 \& MTsN PEKANBARU \\
\hline 2015 & 254.255 .430 & 2.847 .240 .340 & 8,93 Kali & 100 & Sangat Baik \\
\hline 2016 & 247.465 .460 & 2.758 .017 .955 & 8,97 Kali & 100 & Sangat Baik \\
\hline 2017 & 261.045 .400 & 2.936 .462 .724 & 8,89 Kali & 100 & Sangat Baik \\
\hline 3. KOPERASI SEGAR INDAH & \multicolumn{5}{|l|}{} \\
\hline 2015 & 47.389 .500 & 979.908 .924 & 4,84 Kali & 100 & Sangat Baik \\
\hline 2016 & 42.840 .000 & 95.035 .6770 & 4,51 Kali & 100 & Sangat Baik \\
\hline 2017 & 51.939 .000 & 1.009 .461 .077 & 5,15 Kali & 100 & Sangat Baik \\
\hline 4. KOPERASI SEJAHTERA SMAN 5 PEKANBARU \\
\hline 2015 & 1.206 .544 .377 & 1.797 .023 .391 & 67,14 Kali & 100 & Sangat Baik \\
\hline 2016 & 24.698 .000 & 1.878 .470 .344 & 1,31 Kali & 25 & Kurang Baik \\
\hline 2017 & 2.388 .390 .753 & 1.715 .576 .438 & 139,22 Kali & 100 & Sangat Baik \\
\hline 5. KOPERASI PRIMA BADAN KEPEGAWAIAN DAERAH PROVINSI RIAU & Sangat Baik \\
\hline 2015 & 25.811 .000 & 450.203 .520 & 5,73 Kali & 100 & Sangat Baik \\
\hline 2016 & 21.622 .000 & 465.072 .326 & 4,65 Kali & 100 & Sali \\
\hline
\end{tabular}




\begin{tabular}{|c|c|c|c|c|c|}
\hline Tahun & Pendapatan (Rp) & Asset (Rp) & $\begin{array}{c}\text { Perputaran } \\
\text { Aktiva }\end{array}$ & Nilai & Kriteria \\
\hline 2017 & 30.000 .000 & 435.334 .713 & 6,89 Kali & 100 & Sangat Baik \\
\hline \multicolumn{6}{|c|}{ 6. KOPERASI PENGAYOMAN PEGAWAI DEPARTEMEN KEHAKIMAN } \\
\hline 2015 & 142.823 .750 & 1.013.344.258 & 14,09 Kali & 100 & Sangat Baik \\
\hline 2016 & 133.240 .000 & 902.932 .643 & 14,76 Kali & 100 & Sangat Baik \\
\hline 2017 & 152.407 .500 & 1.123 .755 .872 & 6,89 Kali & 100 & Sangat Baik \\
\hline \multicolumn{6}{|c|}{ 7. KP-RI KESUMA NEGERI 1} \\
\hline 2015 & 246.145 .000 & 1.953 .071 .950 & 12,60 Kali & 100 & Sangat Baik \\
\hline 2016 & 252.225 .000 & 1.876.319.553 & 13,44 Kali & 100 & Sangat Baik \\
\hline 2017 & 240.065 .000 & 2.029 .824 .346 & 11,83 Kali & 100 & Sangat Baik \\
\hline \multicolumn{6}{|c|}{ 8. KOPERASI PEGAWAI LOGISTIK RIAU } \\
\hline 2015 & 3.595 .737 .771 & 8.173 .220 .148 & 43,99 Kali & 100 & Sangat Baik \\
\hline 2016 & 3.576 .578 .000 & 8.970 .098 .114 & 39,87 Klai & 100 & Sangat Baik \\
\hline 2017 & 3.614 .897 .542 & 7.376 .342 .182 & 49,02 Kali & 100 & Sangat Baik \\
\hline \multicolumn{6}{|c|}{ 9. KOPERASI KORPRI RIAU } \\
\hline 2015 & 548.960 .270 & 4.610 .139 .220 & 11,91 Kali & 100 & Sangat Baik \\
\hline 2016 & 508.798 .980 & 4.540 .974 .003 & 10,87 Kali & 100 & Sangat Baik \\
\hline 2017 & 589.121 .560 & 4.679 .304 .436 & 12,97 Kali & 100 & Sangat Baik \\
\hline \multicolumn{6}{|c|}{ 10. KPRI BINA TANI } \\
\hline 2015 & 47.458 .700 & 264.427 .516 & 17,95 Kali & 100 & Sangat Baik \\
\hline 2016 & 45.700 .000 & 217.267 .556 & 21,03 Kali & 100 & Sangat Baik \\
\hline 2017 & 49.217 .400 & 311.587 .476 & 15,80 Kali & 100 & Sangat Baik \\
\hline \multicolumn{3}{|c|}{ Rata-Rata } & 21,96 Kali & 100 & Sangat Baik \\
\hline
\end{tabular}

Sumber : Data Olahan, 2018.

Berdasarkan Tabel di atas, dapa dilihat bahwa dari 10 Koperasi KPRI di Kota Pekanbaru,dalam kurun waktu Tahun 2015-2017, terdapat 9 Koperasi yang memiliki kinerja tetap dan berada dalam kategori sangat baik dengan niali 100. Koperasi yang memiliki nilai berfluktuasi dari tahun ke tahun yaitu koperasi Sejahtera SMAN 5 Pekanbaru. Maka dapat disimpulkan bahwa kinerja keuangan Koperasi KPRI di Kota Pekanbaru jika ditinjau dari Perputaran Aktiva, dengan nilai rata-rata sebesar 21,96 Kali, berada pada kriteria Sangat Baik.

Rata-rata keseluruhan berada pada kriteria Sangat Baik menggambarkan bahwa seluruh koperasi telah mampu untuk memanfaatkan asset yang besar dan diimbangi dengan peningkatan pendapatan. Namun hal ini tidak sejalan dengan penelitian Habibah (2013) bahwa hasil penelitian menyatakan bahwa perhitungan perputaran aktiva berada pada kriteria cukup baik.

\section{KESIMPULAN DAN REKOMENDASI KEBIJAKAN}

\section{Kesimpulan}

Berdasarkan hasil penelitian kinerja keuangan berdasarkan 8 rasio maka dapat diberikan kesimpulan sebagai berikut :

1 Kinerja keuangan koperasi KPRI di Kota Pekanbaru jika ditinjau dari Curent Ratio, dengan nilai rata-rata sebesar $377,05 \%$, berada pada kriteria Tidak Baik.

2 Kinerja keuangan koperasi KPRI di Kota Pekanbaru jika ditinjau dari total hutang (kewajiban) terhadap asset, dengan nilai rata-rata sebesar $36,83 \%$, berada pada kriteria Sangat Baik. 
3 Kinerja keuangan koperasi KPRI di Kota Pekanbaru jika ditinjau dari total Hutang (kewajiban) terhadap modal sendiri, dengan nilai rata-rata sebesar $70,02 \%$, berada pada kriteria Sangat Baik.

4 Kinerja keuangan Koperasi KPRI di Kota Pekanbaru jika ditinjau dari Net Profit Margin, dengan nilai rata-rata sebesar $23,45 \%$, berada pada kriteria Sangat Baik.

5 Kinerja keuangan Koperasi KPRI di Kota Pekanbaru jika ditinjau dari Retrun On Asset, dengan nilai rata-rata sebesar 6,56\%, berada pada kriteria Cukup Baik.

6 Kinerja keuangan Koperasi KPRI di Kota Pekanbaru jika ditinjau dari Rentabilitas Modal Sendiri, dengan nilai rata-rata sebesar 11,86\%, berada pada kriteria Cukup Baik.

7 Kinerja keuangan Koperasi KPRI di Kota Pekanbaru jika ditinjau dari Perputaran Piutang, dengan nilai rata-rata sebesar 71,96 Kali, berada pada kriteria Sangat Baik.

8 Kinerja keuangan Koperasi KPRI di Kota Pekanbaru jika ditinjau dari Perputaran Aktiva, dengan nilai rata-rata sebesar 21,96 Kali, berada pada kriteria Sangat Baik.

\section{Rekomendasi Kebijakan}

Hal-hal yang dapat disarankan berdasarkan hasil penelitian dan pembahasan adalah Untuk meningkatkan rasio keuangannya, sebaiknya Koperasi KPRI di Kota Pekanbaru, lebih mengoptimalkan penggunaan asset, modal sendiri, dan total hutang untuk menjalankan usahanya, dimana dengan melakukan restrukturisasi aktiva-aktiva agar aktiva yang kurang produktif mampu menjadi aktiva yang produktif. Sebaiknya Koperasi KPRI di Kota Pekanbaru mampu memanfaatkan dana dari luar, namun jangan sampai ketergantungan dalam mempergunakan modal dari luar penguatan modal sendiri yang berasal dari simpanan pokok, simpanan wajib, cadangan, donasi, sumbangan, penyertaan, SHU tahun berjalan dan SHU yang tidak dibagi terus ditingkatkan kemampuan sesuai dengan kesepakatan pada saat RAT. Menentukan jatuh tempo pembayaran piutang barang maupun uang yang disedikana bagi anggota agar menjamin pembayaran kewajiban. Sebaiknya Koperasi KPRI di Kota Pekanbaru, secara rutin dapat melakukan analisis laporan keuangan. Dengan menggunakan laporan keuangan maka akan dapat diketahui apabila ada kelemahan-kelemahan yang berkaitan dengan kinerja keuangan, sehingga dapat segera diperbaiki.Selain itu pada periode berikutnya dapat dilakukan pencegahan dari kelemahan tersebut.

\section{DAFTAR PUSTAKA}

Anoraga, Pandji dan Widiyanti, Ninik. 2003. Dinamika Koperasi. Jakarta. Penerbit PT. Bina Adiaksara dan PT. Rineka Cipta.

Bale, Yohanes Leu. 2010. Analisis Kineja Keuangan Pada Koperasi Pegawai Republik Indonesia Guru-Guru Lembata (KPRI Gurita). http://repository.ut.ac.id/1055/1/40579.pdf. 14 Agustus 2018.

Darmawati. 2007. Analisis Kinerja Keuangan pada Koperasi Simpan Pinjam Binaan Aceh Micro Finance(AMF) Di Kota Lhoksumawe. Jurnal eksekutif, volume 4, Nomor 3.

Erindani, Ardha. 2015. Analisis Kinerja Keuangan Pada Koperasi Pegawai Republik Indonesia (KPRI) "Kencana Kulya" Kota Kediri. http://jurnalmahasiswa.unesa.ac.id/index.php/jupe/article/view/9236/9173. 1 Agustus. 2018

Habibah, Nur Fitria. 2013. Analisis Kinerja Keuangan Pada Koperasi Pegawai Republik Indonesia "Garuda" Kecamatan Randudongkal Periode 2011-2012. http://eprints.dinus.ac.id/8705/1/jurnal_13245.pdf. 5 Agustus 2018. 
Huda, Choirul., Mardani Ronny Malavia dan Salim, M. Agus. 2017. Analisis Kinerja Keuangan Koperasi Karyawan Melati Husada Malang (studi kasus pada koperasi karyawan Melati Husada Malang periode 2012 - 2016).

http://riset.unisma.ac.id/index.php/jrm/article/viewFile/563/586. 15 Agustus 2018.

Ikatan Akuntan Indonesia. 2007. Standar Akuntan Keuangan. Jakarta: Salemba Empat.

Ilham, Muhammad Reza. 2011. Analisis Kinerja Keuangan Koperasi Di Koperasi Keluarga Pegawai ITB. https://repository.ipb.ac.id/handle/123456789/51989. 5 Agustus 2018.

Jumingan. 2006. Analisis Laporan Keuangan. Jakarta: Bumi Aksara.

Munawir. 2001. Analisis Laporan Keuangan. Yogyakarta: Liberty.

Peraturan Menteri Negara Koperasi dan Usaha Kecil dan Menengah Republik Indonesia Nomor : 06/Per/M.KUKM/V/2006 Tanggal : 1 Mei 2006 Tentang : Pedoman Penilaian Koperasi Berprestasi/Koperasi Award

Rachmawati, Rizki. 2013. Analisis Rasio Keuangan Untuk Menilai Kinerja Keuangan Koperasi Pegawai Republik Indonesia (Kpri) Tegak Kecamatan Sentolo Kulonprogo. http://eprints.uny.ac.id/17704/1/TUGAS\%20AKHIR.pdf. 5 Agustus 2018.

Rudianto. 2010. Akuntansi Koperasi Edisi 2. Jakarta: Erlangga

Sari, I Gusti Ayu Nyomaya dan Mahmudah Nurul. 2017. Analisis Kinerja Keuangan Pada Koperasi Pegawai Republik Indonesia (KPRI) Handayani Kabupaten Pemalang. Periode 2011-2015. http://ejournal.poltektegal.ac.id/index.php/monex/article/view/597. 3 Agustus 2018.

Umar, Husen.2008. Metode Riset Bisnis. Jakarta: PT Gramedia Pustaka Utama.

Wirawan. 2007. Budayadan Iklim Organisasi Teori Aplikasi dan Penelitian. Jakarta : Salemba Empat. 